\title{
A Study on Socio-economic Profile of the Dairy Farmers in Central Plain Zone of Uttar Pradesh
}

\author{
Awadhesh Kumar Singh*, Arun Kumar Singh and Saikat Maji \\ Department of Extension Education, IAS, BHU, Varanasi, India \\ *Corresponding author
}

\section{A B S T R A C T}

Keywords

Milk production, Communication, Dairy farming, Education

Article Info

Accepted:

12 December 2020

Available Online:

10 January 2021
Dairy farming play very important role in improving the income of the farmers. The study was conducted to investigate the socio-economic and communication profile of the dairy farmers of central plain zone of Uttar Pradesh. The present explore the different aspect of dairy farming and status of milk production, consumption and sale. For the study central plain zone and Uttar Pradesh was selected purposively. From the zone two districts were selected randomly and from the each district two blocks were selected randomly. Two villages from each block were selected randomly. 10 per cent of dairy farmers were selected proportionate randomly sampling from the total household of each village. The criteria of the respondents were the dairy farmers should have at least one lactating dairy animal at the time of investigation. From the study it was observed that majority $(46.97 \%)$ of the respondents belong to middle age group and 25.15 per cent respondents had middle education category. 47.27 per cent respondents had more than 25 year of experience in dairying and 57.27 per cent respondents had medium family size. 56.67 per cent respondents had medium level of income and 70.00 per cent respondents had crop farming as their primary occupation.46.36 per cent respondents had less than one hectare of land. in case of milk production more than half $(50.03 \%)$ of the respondents fall in medium category. 56.36 per cent respondents had medium level of social participation and 49.39 per cent respondents had medium level of mass media exposure.

\section{Introduction}

Dairy Farming is a class of agricultural, rearing of cattle, baffalos and goats, or certain other milch animal for long term milk production, which may be either processed on site or transported to organized dairy for processing (Shinde, 2011). Dairy farming being the major contributor to the overall GDP of the country, the overall contribution of Livestock Sector in total GDP was nearly
4.11 per cent at current prices during 2012-13 (NDDB-2012-13). Dairy farming is a main source of additional income to small farmers, marginal farmers and agricultural laborers in the state. The dairy farming has an important role in subsistence farming as well as commercial farming for low as well as moderate income households. Dairy sector have great potentiality and scope for enhancing the socio- economic situation of small, marginal farmers and agricultural 
laborers since it provides higher production and profit short time as compared to others enterprises. It has more income, employment generation and man day's works force in short span of time in the state. The dairy farmers of Uttar Pradesh rear lactating animals for the generating of income which is complementary for the crop farming. If we see the growing trends of population in the state it must be required to fulfill the food security as well as nutritional security through milk and milk products. Another scenario is that the population raises different issues related to food insecurity, notional insecurity, unemployment etc. for the overcome of these issues the government is taking effective and efficient steps. The present study was conducted to study the socio-economic and communication profile of dairy farmers in central plain zone of Uttar Pradesh.

\section{Materials and Methods}

The study was conducted to explore the different aspect of dairy farming and status of milk production utilization and sale. For the study central plain zone and Uttar Pradesh was selected purposively. From the zone two districts were selected randomly and from the district four blocks were selected randomly. Two villages from each block were selected randomly. 10 per cent of dairy farmers were selected proportionate randomly sampling from the total farmers of each village. Thus, total number of sample size was 330. The criteria of the respondents are the dairy farmers should have at least one lactating dairy animal at the time of investigation. Primary method of data collection was conducted through a structured interview schedule which was developed for this purpose. The variable of the study was includes such as age, education, family size, herd size, operational land holding, annual income, experience in dairying, milk production, milk utilization, milk sale, social participation, personal contact, personal cosmopolite and mass media exposure. The data collected was analyzed using simple statistical tools like frequency and percentage.

\section{Results and Discussion}

\section{Age}

The information regarding the age group of the respondents is important in getting an insight about the potential human resources. It is evident from Table 1 that majority of the respondents $(46.97 \%)$ were from the age group of 36-50 years followed by the 33.33 per cent of the respondents, who belonged to more than 50 years age group and near about one fifth of the respondents $(19.70 \%)$ were belonged to the age category of upto 35 years. similar finding of Atreya et al., (2018) observed that in case of member dairy farmers the majority of respondents $(58.00 \%)$ were observed in middle age group.

\section{Education}

Educational status of the dairy farmers is an important aspect while assessing their knowledge level and adaptability of good dairy farming practices. Perusal of Table: 1 was observed that majority of the respondents $(25.15 \%)$ had middle level of schooling, followed by 21.52 per cent of the respondents who had secondary level of schooling. Furthermore, it was found that 16.67 per cent and 14.24 per cent of the respondents had secondary level of education and primary level of education respectively. More than one-tenth of the respondents $(11.21 \%)$ had educational level graduation and above. 7.88 per cent and 3.33 per cent of the respondents were belonged to functionally literate and illiterate category respectively. Prashad et al., (2019) from the study it was indicated that majority $(37.50 \%)$ of dairy farmers had high school level of education followed by 
graduation and above $(20.83 \%)$, intermediate $(20.00 \%)$ middle school.

\section{Experience in Dairy farming}

Experience in dairy farming is very important for the dairy farmers in managing milch animals properly. According to Table: 1 majority $(47.27 \%)$ of the respondents had more than 25 years of experience in dairy farming followed by 28.79 per cent and 23.94 per cent of the respondents had 17 to 25 years and less than 17 years of experience in dairy farming. Thankachan and Joseph (2019) reported that 35.00 per cent of the respondents are those who have dairying experience ranging from 16 to 25 years.

\section{Family Size}

According to Table: 1 more than half $(57.27 \%)$ of the respondents had medium sized family comprising of 5 to 7 members, followed by 23.03 per cent of the respondents had high family size with more than 7 members and 19.70 per cent of the respondents had low family size with less than 5 members. Prashad et al., (2019) observed that majority $(53.33 \%)$ of dairy farmers had medium size families that is 5-10 members

\section{Operational land Holding (OLH)}

In this research the actual land possessed by the respondent were indicated. Perusal of Table: 1 was found that majority of the respondents $(46.36 \%)$ were marginal land holders which were followed by 24.24 percent and 20.00 percent of the respondents who were small and land holders respectively. A very less proportion of the respondents $(5.45 \%)$ had medium land holding followed by 3.94 per cent of the respondents who were land less. None of the respondents had land holding. Rajadurai et al., (2018) observed that maximum number of respondents were landless $(71.40 \%)$, while small farmers $(17.70 \%)$.

\section{Occupation}

A glance at Table: 1 reported that majority of the respondents $(70.00 \%)$ had Agriculture as their primary occupation. 10.30 per cent of the respondents practiced Dairying as their major occupation followed by 7.58 per cent, 6.36 per cent and 5.76 per cent of the respondents who choose Labor work, Business and Service sector as their major occupation. On the other hand, majority of the respondents $(75.15 \%)$ choose Dairying as their secondary occupation, followed by 20.00 per cent of the respondents who had agriculture as their secondary occupation. Whereas, very few respondents i.e 3.94 per cent and 0.91 per cent of the respondents had Labor work and Business as their secondary occupation, respectively. None of the respondents choose service sector as their major occupation. Dairy farming involves high initial cost for taking up as a primary occupation in large scale basis. So majority of the farmers consider it as a secondary source of income as Agriculture and Dairying are complementary to each other and they continue Dairying in a small scale basis for regular income generation. Similar finding of Prashad et al., (2019) observed that majority $(80.00 \%)$ of respondents had crop farming as their main occupation.

\section{Herd Size}

It was depicted from table: 1 that about 48.79 per cent of the respondents were in medium herd size category i.e. 3 to 4 , followed by 38.48 per cent fall under small category of herd size $(<3)$ and only 12.73 per cent fall in large category of herd size $(>4)$. Farmers reared dairy animals generally for their self consumption and surplus milk were sold to 
the milk vendor and milk co-operative society (PARAG). Prashad et al., (2019) reported that the maximum number $(53.33 \%)$ of respondents had small (up to 3 milch animals) herd size

\section{Annual income:}

According to Table: 1 majority (56.67\%) of the respondents had medium income level ranging from 0.75 to 1.5 lakhs followed by 23.64 per cent of the respondents had low income level of less than 0.75 lakhs and 19.70 per cent of the respondents had high income level of more than 1.5 lakhs. Atreya et al., (2018) reported that majority $(63.00 \%)$ of the member respondents were in low annual income category, followed by 24.00 and 13.00 percent of member respondents were in medium and high annual income category.

Table.1 Distribution of respondents as per Socio-economic and communication profile $(n=330)$

\begin{tabular}{|c|c|c|c|}
\hline \multicolumn{2}{|l|}{ Category } & Frequency & Percentage \\
\hline \multirow[t]{4}{*}{ Age } & & & \\
\hline & Young age (upto 35) & 65 & 19.70 \\
\hline & Middle age (36-50) & 155 & 46.97 \\
\hline & Old age(above 50) & 110 & 33.33 \\
\hline \multicolumn{4}{|l|}{ Family Size } \\
\hline & Small $(<5)$ & 65 & 19.70 \\
\hline & Medium (5to7) & 189 & 57.27 \\
\hline & Large $(>7)$ & 76 & 23.03 \\
\hline \multicolumn{4}{|l|}{ Education } \\
\hline & Illiterate & 11 & 3.33 \\
\hline & Functionally literate & 26 & 7.88 \\
\hline & Primary & 47 & 14.24 \\
\hline & Middle & 83 & 25.15 \\
\hline & Secondary & 71 & 21.52 \\
\hline & Intermediate & 55 & 16.67 \\
\hline & Graduate and above & 37 & 11.21 \\
\hline \multicolumn{4}{|l|}{ Occupation } \\
\hline \multirow[t]{5}{*}{ Primary } & Agriculture & 231 & 70.00 \\
\hline & Dairying & 34 & 10.30 \\
\hline & Service & 19 & 5.76 \\
\hline & Business & 21 & 6.36 \\
\hline & Labor & 25 & 7.58 \\
\hline \multirow[t]{4}{*}{ secondary } & Agriculture & 66 & 20.00 \\
\hline & Dairying & 248 & 75.15 \\
\hline & Business & 3 & 0.91 \\
\hline & Labor & 13 & 3.94 \\
\hline \multirow{4}{*}{$\begin{array}{l}\text { Experience in } \\
\text { dairying }\end{array}$} & & & \\
\hline & Low $(<17)$ & 79 & 23.94 \\
\hline & Medium (17to25) & 95 & 28.79 \\
\hline & $\operatorname{High}(>25)$ & 156 & 47.27 \\
\hline
\end{tabular}




\begin{tabular}{|c|c|c|c|}
\hline \multirow[t]{4}{*}{ Herd size } & & & \\
\hline & Small $(<3)$ & 127 & 38.48 \\
\hline & Medium (3to4) & 161 & 48.79 \\
\hline & Large $(>4)$ & 42 & 12.73 \\
\hline \multirow{7}{*}{$\begin{array}{l}\text { Operational land } \\
\text { holding }\end{array}$} & & & \\
\hline & Landless (0 ha) & 13 & 3.94 \\
\hline & Marginal $<1$ ha & 153 & 46.36 \\
\hline & Small 1-2 ha & 80 & 24.24 \\
\hline & Semi- medium 2.1-4 ha & 66 & 20.00 \\
\hline & Medium 4.1-10 ha & 18 & 5.45 \\
\hline & Large $>10$ ha & 0 & 0.00 \\
\hline \multirow[t]{4}{*}{ Annual Income } & & & \\
\hline & Low (<0.75 lakh) & 78 & 23.64 \\
\hline & Medium (0.75to1.5 lakh) & 187 & 56.67 \\
\hline & High $(>1.5$ lakh $)$ & 65 & 19.70 \\
\hline \multirow[t]{4}{*}{ Milk production } & & & \\
\hline & Low $(<5)$ & 87 & 26.36 \\
\hline & Medium (5to9) & 126 & 38.18 \\
\hline & $\operatorname{High}(>9)$ & 117 & 35.45 \\
\hline \multirow[t]{4}{*}{ Milk consumption } & & & \\
\hline & Low $(<2)$ & 119 & 36.06 \\
\hline & Medium (2to3) & 175 & 53.03 \\
\hline & $\operatorname{High}(>3)$ & 36 & 10.91 \\
\hline \multirow[t]{4}{*}{ Milk sale } & & & \\
\hline & Low $(<4)$ & 117 & 35.45 \\
\hline & Medium (4to7) & 131 & 39.70 \\
\hline & $\operatorname{High}(>7)$ & 82 & 24.85 \\
\hline \multirow[t]{4}{*}{ Social participation } & & & \\
\hline & Low $(<3)$ & 92 & 27.88 \\
\hline & Medium (3to5) & 186 & 56.36 \\
\hline & medium $(>5)$ & 52 & 15.76 \\
\hline \multirow{4}{*}{$\begin{array}{l}\text { Personal localite } \\
\text { contacts }\end{array}$} & & & \\
\hline & Low $(<6)$ & 109 & 33.03 \\
\hline & Medium (6to7) & 175 & 53.03 \\
\hline & $\operatorname{High}(>7)$ & 46 & 13.94 \\
\hline \multirow{4}{*}{$\begin{array}{l}\text { Personal cosmopolite } \\
\text { contacts }\end{array}$} & & & \\
\hline & Low $(<3)$ & 74 & 22.42 \\
\hline & Medium (3to4) & 197 & 59.70 \\
\hline & $\operatorname{High}(>4)$ & 59 & 17.88 \\
\hline \multirow[t]{4}{*}{ Mass media exposure } & & & \\
\hline & Low $(<7)$ & 117 & 35.45 \\
\hline & Medium (7to8) & 163 & 49.39 \\
\hline & High $(>8)$ & 50 & 15.15 \\
\hline
\end{tabular}




\section{Milk production}

Milk production was calculated in terms of the amount of milk produced in Litre on per day basis from the lactating animals. A bird's eye view of milk production in Table: 1 found that majority (38.18\%) of the respondents had lactating animals that produce 6 to 10 litres of milk per day as they practiced.

Dairying in a small scale basis followed by 35.45 per cent and 26.36 per cent of the respondents had lactating animals that produce more than 10 litres and less than 6 litres of milk respectively. Prasad et al., (2017) revealed that the average milk yield of cattle was 66.00 per cent

\section{Milk consumption}

Consumption of the milk was calculated in terms of the amount of milk in liters, consumed by the household of the respondent's per day basis. Perusal of Table: 1 observed that slightly more than half $(53.03 \%)$ of the respondents consumed 3 to 4 litres of the milk per day which was followed by 36.06 per cent and 10.91 per cent of the respondents who consumed less than 3 litres and more than 4 litres of milk per day basis for household consumption purpose.

\section{Milk sale}

Milk sale was presented as the amount of milk being sold by the respondents on daily basis. A glance at Table: 1 was found that majority $(39.70 \%)$ of the respondents sold 5 to 8 liters of milk per day followed by 35.45 per cent and 24.85 per cent of the respondents who sold less than 5 liters and more than 8 litres of milk respectively.

Koli et al., (2020) revealed that majority of the respondents $(92.50 \%)$ had medium level of milk sale category

\section{Social participation}

According to Table: 1 majority (56.36\%) of the respondents had medium level of social participation followed by 27.88 per cent and 15.76 per cent of the respondents who had low and high social participation respectively. social participation of the respondents were satisfactory because of some farmers engaged in cooperative society as a member. Sachan (2013) reported that majority $(65.00 \%)$ of the respondents had low level of social participation, followed by 28.00 per cent medium level.

\section{Personal localite}

A bird's eye view of personal localite in Table: 1 reported that more than half $(53.03 \%)$ of the respondents belonged to the medium personal localite category whereas 33.03 per cent and 13.94 per cent of the respondents belonged to low and high personal localite category. Manjunath et al., (2020) observed that majority $(55.00 \%)$ of the respondents had medium extension contact.

\section{Personal cosmopolite}

Perusal of Table: 1 revealed that majority $(59.70 \%)$ of the respondents belonged to the medium personal cosmopolite category followed by 22.42 percent and 17.88 percent of the respondents belonged to low and high personal cosmopolite category.

\section{Mass media exposure}

A glance at Table: 1 was found that near about half of the respondents $(49.39 \%)$ had medium mass media exposure followed by 35.45 percent and 15.15 per cent of the respondents who had low and high mass media exposure respectively because most of the farmers having Smartphone's, internet 
connection, television etc. Manjunath et al., (2020) in his study observed that majority $(60.00 \%)$ of the respondents belonged to medium mass media exposure.

In conclusion dairy farming plays important role in income generation of small and marginal farmers in Uttar Pradesh. From the study it was observed that majority of respondents had medium level of age category. Agriculture was the primary and dairy was secondary occupation in the study area.

Respondents having more crossbred cattle and buffalo as compare to indigenous cattle because higher milk production was main objective of the farmers. Generally farmers sale their milk in co-operative society and some farmers sale in private shops.

Respondents having medium mass media exposure because most of the farmers having Smartphone's, internet connection, television etc. social participation of the respondents were satisfactory because of some farmers engaged in cooperative society as a member.

\section{Acknowledgement}

The authors thankfully acknowledge Director and Advisor, Institute of Agricultural Sciences and vice-chancellor Banaras Hindu University, Varanasi for providing facilities and valuable guidance for the research work.

\section{References}

Gautam, R., Malik, Sangwan, A., Khirbat, S.S., Richa and Kamaldeep 2017. Socio-economic profile of dairy farmers in Hisar district of Haryana. Asian Journal of Animal Sciences. 12(1): 8894.

Koli, R. T., Mankar, D. M., Tekale, V. S. and Bhople, P. P. 2020. Personal, socio- economic, communication and psychological characteristics of dairy farmers. International Journal of Chemical Studies. 8(1): 490-493.

Manjunath, M., Kumar, K. A., Kale, S., Barikar, U. and Sreenivas. B. V. 2020. Socio-economic profile analysis of dairy farmers of Yadgir district of Kalyana Karnataka region. Journal of Pharmacognosy and Phytochemistry. 9(4): 350-353.

Prasad, K., Savale, S., Mahantesh, M. T., Pavan, M., Barman, D. and John, A. 2017. Socio-Economic Profile and Constraints Faced By Dairy Farmers of Wayanad District, India. International Journal of Current Microbiology and Applied Sciences. 6(6): 870-874.

Ram, D. H., Kumar, R., Chaudhari, G. M., vekariya, S. J. and Savsani, H. H. 2018. A Socio-economic Profile of the Unorganized Dairy Farmers. International Journal of Agricultural Science and Research. 8(5):49-54.

Atreya, S., Singh, P., Kumar, S., Kumar, M., Prashad, K. and Kishore, K. 2018. Socio-Economic Profile of the Dairy Farmers in Sultanpur District of Uttar Pradesh. International Journal of Agriculture Sciences. 10(12):63686372.

Sachan, R. 2013. Buffalo Husbandry Practices Among Dairy Farmers in Unnao district of Uttar Pradesh. M.V.Sc. Thesis, ICAR-NDRI (Deemed to be University), Karnal, Haryana, India.

Prasad, N., Kumar, S., Pandey, M., Soni, Y. K., Saha, S., Chand, N. and Arya S. 2019. Socio-Economic Status and Problems Faced by Dairy Farmers of Sardhana Block of Meerut District. International journal of livestock research, 9(4):120-128. 


\section{How to cite this article:}

Awadhesh Kumar Singh, Arun Kumar Singh and Saikat Maji. 2021. A Study on Socioeconomic Profile of the Dairy Farmers in Central Plain Zone of Uttar Pradesh. Int.J.Curr.Microbiol.App.Sci. 10(01): 988-995. doi: https://doi.org/10.20546/ijcmas.2021.1001.120 